\title{
A Protein Isolate from Moringa oleifera Leaves Has Hypoglycemic and Antioxidant Effects in Alloxan-Induced Diabetic Mice
}

\author{
Paulo C. Paula ${ }^{1}$, Daniele O. B. Sousa ${ }^{1, *}$, Jose T. A. Oliveira ${ }^{1}$, Ana F. U. Carvalho ${ }^{2}$, \\ Bella G. T. Alves ${ }^{1}$, Mirella L. Pereira ${ }^{1}$, Davi F. Farias ${ }^{1,3}{ }^{\text {, Martonio P. Viana }}{ }^{1}$, Flavia A. Santos ${ }^{4}$, \\ Talita C. Morais ${ }^{4}$ and Ilka M. Vasconcelos ${ }^{1, *}$ \\ 1 Department of Biochemistry and Molecular Biology, Federal University of Ceara, Fortaleza 60440-900, Brazil; \\ paulolevemir@gmail.com (P.C.P.); jtaolive@ufc.br (J.T.A.O.); bellaagiselly@gmail.com (B.G.T.A.); \\ mirellasally@gmail.com (M.L.P.); davi@dbm.ufpb.br (D.F.F.); vianamp@hotmail.com (M.P.V.) \\ Department of Biology, Federal University of Ceara, Fortaleza 60440-900, Brazil; aurano@ufc.br \\ Department of Molecular Biology, Federal University of Paraiba, Joao Pessoa 58051-900, Brazil \\ 4 Department of Physiology and Pharmacology, Federal University of Ceara, Fortaleza 60430-160, Brazil; \\ flavia@ufc.br (F.A.S.); talita.cm@hotmail.com (T.C.M.) \\ * Correspondence: danisilas@yahoo.com.br (D.O.B.S.); imvasco@ufc.br (I.M.V.); \\ Tel.: +55-85-3366-9820 (D.O.B.S.); +55-85-3366-9822 (I.M.V.); Fax: +55-85-3366-9789 (D.O.B.S. \& I.M.V.)
}

Academic Editor: Philippe Bulet

Received: 17 January 2017; Accepted: 9 February 2017; Published: 11 February 2017

\begin{abstract}
Moringa oleifera has been used in traditional medicine to treat diabetes. However, few studies have been conducted to relate its antidiabetic properties to proteins. In this study, a leaf protein isolate was obtained from $M$. oleifera leaves, named Mo-LPI, and the hypoglycemic and antioxidant effects on alloxan-induced diabetic mice were assessed. Mo-LPI was obtained by aqueous extraction, ammonium sulphate precipitation and dialysis. The electrophoresis profile and proteolytic hydrolysis confirmed its protein nature. Mo-LPI showed hemagglutinating activity, cross-reaction with anti-insulin antibodies and precipitation after zinc addition. Single-dose intraperitoneal (i.p.) administration of $\mathrm{Mo}$-LPI (500 mg/kg.bw) reduced the blood glucose level (reductions of 34.3\%, 60.9\% and $66.4 \%$ after 1,3 and $5 \mathrm{~h}$, respectively). The effect of $M o$-LPI was also evidenced in the repeated dose test with a $56.2 \%$ reduction in the blood glucose level on the 7 th day after i.p. administration. Mo-LPI did not stimulate insulin secretion in diabetic mice. Mo-LPI was also effective in reducing the oxidative stress in diabetic mice by a decrease in malondialdehyde level and increase in catalase activity. Mo-LPI (2500 $\mathrm{mg} / \mathrm{kg} \cdot \mathrm{bw})$ did not cause acute toxicity to mice. Mo-LPI is a promising alternative or complementary agent to treat diabetes.
\end{abstract}

Keywords: Moringa; plant protein; hypoglycemic activity; antioxidant activity; diabetes therapy

\section{Introduction}

Diabetes is a chronic disease that affects millions of people worldwide. The persistent hyperglycemia associated with this disease promotes the appearance of lesions in organs such as kidneys, eyes, nerves and blood vessels. Glycemic control is very important for avoiding or delaying the development of these complications [1]. It is known that several plant compounds exert hypoglycemic effects, representing potential therapeutic agents for the treatment of diabetes [2]. Small molecules with high structural diversity produced during plant secondary metabolism that promote glycemic normalization, stimulate insulin release, reduce resistance to the tissue action of this hormone and elicit insulin-mimetic effects have been isolated, including terpenes, alkaloids and flavonoids [3]. Although a good deal of credit has been given to these secondary metabolites 
in promoting the hypoglycemic action of orally taken plant extracts, few attention has been paid to observations and data in the literature that relate the antidiabetic properties of plant extracts to proteins [4] and the possibility of their biotechnological use to treat diabetes. In fact, plant proteins have also demonstrated efficient glycemic reduction $[5,6]$. For example, hypoglycemic proteins were purified from Canavalia ensiformis seed coat [7] and Momordica charantia seeds [8]. Lectins have also been shown to exert hypoglycemic effects in vivo [9-11].

Moringa oleifera Lamarck (Moringaceae) is a fast-growing perennial species native to northwestern India, which is now cultivated in many areas worldwide. This species has been used in folk medicine to treat diabetes [12-14]. Additionally, experimental studies have demonstrated that different parts of the plant possess pharmacological properties related to diabetes, such as hypoglycemic activity [15], anti-inflammatory effects [16], protection against oxidative stress [17] and hypolipidemic activity [18]. The hypoglycemic effect is very often credited to plant secondary metabolites and few efforts have been made to determine whether other molecules possess this activity, especially proteins. Plant secondary metabolites are usually extracted using specific solvents and protocols and during these processes, most proteins lose their structural integrity and activity $[19,20]$. To the best of our knowledge, there is only one work done on the hypoglycemic activity of proteins from M. oleifera [21]. In this study carried out by our research group, a protein fraction obtained from the seed coat of M. oleifera, named Mo-SC, promoted a substantial reduction in the glucose levels of alloxan-induced diabetic mice after intraperitoneal or oral administration. To expand our knowledge on the biological properties of M. oleifera proteins, in the present study a protein isolate was obtained from M. oleifera leaves, named Mo-LPI (M. oleifera leaf protein isolate), and its hypoglycemic and antioxidant effects on alloxan-induced diabetic mice were assessed. To clarify the possible mechanism of hypoglycemic action of $M o$-LPI, the serum insulin level was evaluated. The results obtained allow to include definitely M. oleifera as an additional species within the restricted group of plants that possess proteins with hypoglycemic and antioxidant properties. Accordingly, M. oleifera has potential to provide novel protein(s) to compose alternative drug(s) toward treating diabetes.

\section{Results}

\subsection{Biochemical Properties of Mo-LPI}

Mo-LPI corresponds to $4.96 \pm 0.33 \mathrm{mg} / \mathrm{g}$ leaf dry weight and represents $57.5 \%$ of the soluble protein of the leaf crude extract. SDS-PAGE analysis revealed that Mo-LPI is composed of several protein bands, most of which have an apparent molecular mass over $29 \mathrm{kDa}$ and a strong single band in the range of 14-20 kDa, as shown in Figure 1 (Lane 4). Mo-LPI was susceptible to pepsin digestion and virtually all protein bands disappeared after that (Figure 1a). Similar results were observed after incubation with trypsin; 2-h incubation caused complete digestion of Mo-LPI (Figure 1b).

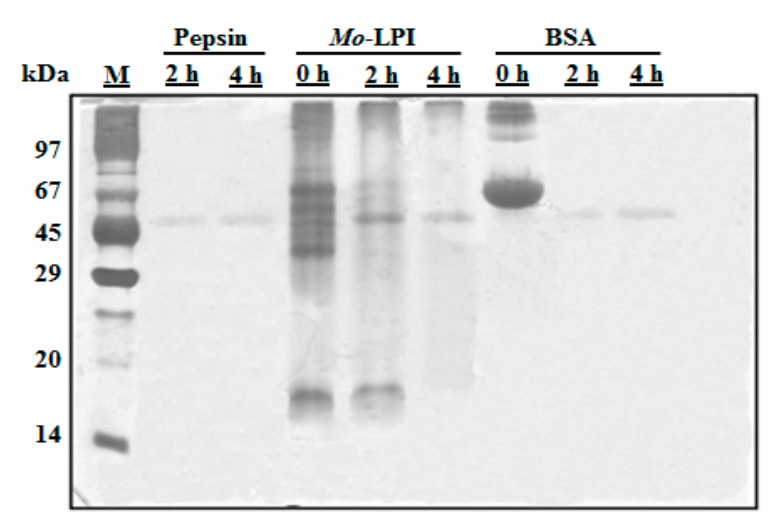

(a)

Figure 1. Cont. 


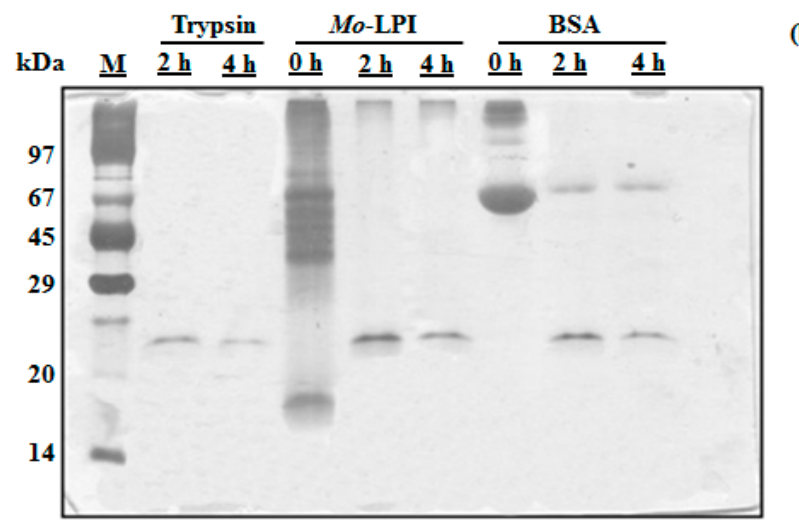

(b)

Figure 1. Assessment of the in vitro digestibility of Mo-LPI by SDS-PAGE analysis. Mo-LPI was incubated with pepsin or trypsin at different times (0, 2 and 4 h). (a) Pepsin digestion; (b) Trypsin digestion. Bovine serum albumin (BSA) was used as control. Twenty microgram from each sample were loaded in each well. Vertical numbers indicate the molecular mass markers: phosphorylase B (97 kDa); BSA (67 kDa); ovalbumin (45 kDa); carbonic anhydrase (29 kDa); trypsin inhibitor (20.1 kDa) and $\alpha$-lactalbumin $(14.2 \mathrm{kDa})$. Horizontal numbers refer to the digestion times $(\mathrm{h})$.

Mo-LPI could not agglutinate rabbit erythrocytes, even at $6 \mathrm{mg} / \mathrm{mL}$. However, agglutinating activity was detected against rat $(1.33 \mathrm{HU} / \mathrm{mg}$ protein) and mouse $(2.67 \mathrm{HU} / \mathrm{mg}$ protein) erythrocytes. These results did not differ regardless of whether the erythrocytes were trypsin-treated or not.

Mo-LPI was able to cross-react with human anti-insulin antibodies as observed in the dot blot assay. A signal could still be visualized at the lowest primary antibody dilution (Figure 2). Moreover, similar to the effects observed with human recombinant insulin, Zn-induced precipitation of Mo-LPI was detected (Figure 3). The proteinaceous nature of this precipitate was confirmed using the Bradford reagent [22].

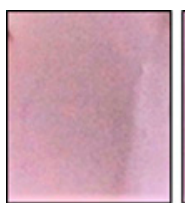

(a)

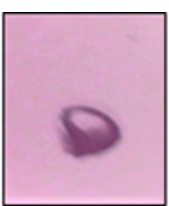

(b)

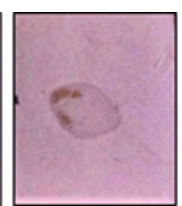

(c)

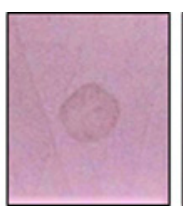

(d)

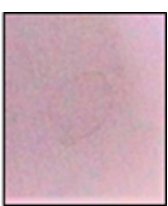

(e)

Figure 2. Dot blot assay using human anti-insulin as primary antibodies. (a) Tris-buffered saline; (b) Human recombinant insulin $(2 \mathrm{mg} / \mathrm{mL}$ ) incubated with human anti-insulin IgG (1:250); (c-e) Mo-LPI $(2 \mathrm{mg} / \mathrm{mL})$ incubated with primary antibodies diluted 1:250, 1:500 and 1:1000, respectively.

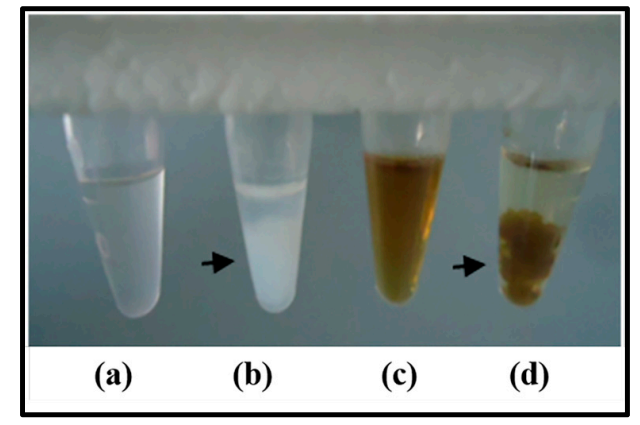

Figure 3. Zn-induced precipitation. (a,c) zinc-free human recombinant insulin ( $5 \mathrm{mg} / \mathrm{mL}$ ) and Mo-LPI $(5 \mathrm{mg} / \mathrm{mL}$ ) solutions in $0.05 \mathrm{M}$ Tris- $\mathrm{HCl}, \mathrm{pH} 7.5$, respectively; (b,d) zinc-free human recombinant insulin and Mo-LPI solutions after the addition of $1 \mathrm{M}$ zinc chloride, respectively. Arrows indicate the protein precipitate. 


\subsection{Effect of Mo-LPI on Fasting Blood Glucose in Alloxan-Induced Diabetic Mice}

The hypoglycemic effect of a single dose of Mo-LPI administered to diabetic mice by i.p. injection is shown in Figure 4. Mo-LPI potentially and significantly $(p<0.01)$ caused a hypoglycemic effect at both doses (300 and $500 \mathrm{mg} / \mathrm{kg} \cdot \mathrm{bw}$ ). The $500 \mathrm{mg} / \mathrm{kg} \cdot \mathrm{bw}$ dose presented better antidiabetic activity, with blood glucose reductions of $34.3 \%, 60.9 \%$ and $66.4 \%$ after 1,3 and $5 \mathrm{~h}$, respectively. After heat treatment of Mo-LPI ( $500 \mathrm{mg} / \mathrm{kg} \cdot \mathrm{bw}$ ) at $98^{\circ} \mathrm{C}$ for $1 \mathrm{~h}$, the hypoglycemic effect was partially abolished. In this case, the effect was only pronounced at $5 \mathrm{~h}$, with a $36.7 \%$ reduction in blood glucose (Figure 5 ). Conversely, no significant hypoglycemic effect was observed in diabetic mice when Mo-LPI was orally administered, even at the highest i.p. dose (Figure 6).

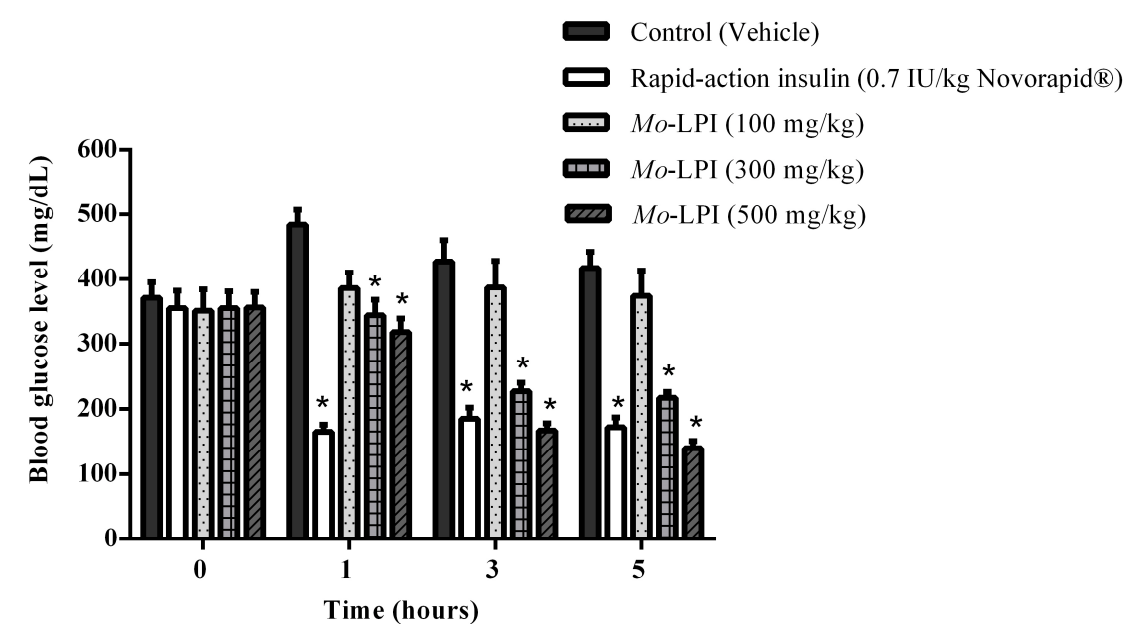

Figure 4. Effect of intraperitoneal administration of Mo-LPI on blood glucose level in alloxan-induced diabetic mice. Values are means \pm S.E.M. $(n=10)$. Control: vehicle $(0.05 \mathrm{M}$ Tris- $\mathrm{HCl}, \mathrm{pH} 7.5$, containing $0.15 \mathrm{M} \mathrm{NaCl})$. ${ }^{*}$ Significant $(p<0.01)$ difference when compared with the corresponding value of the control at the same time.

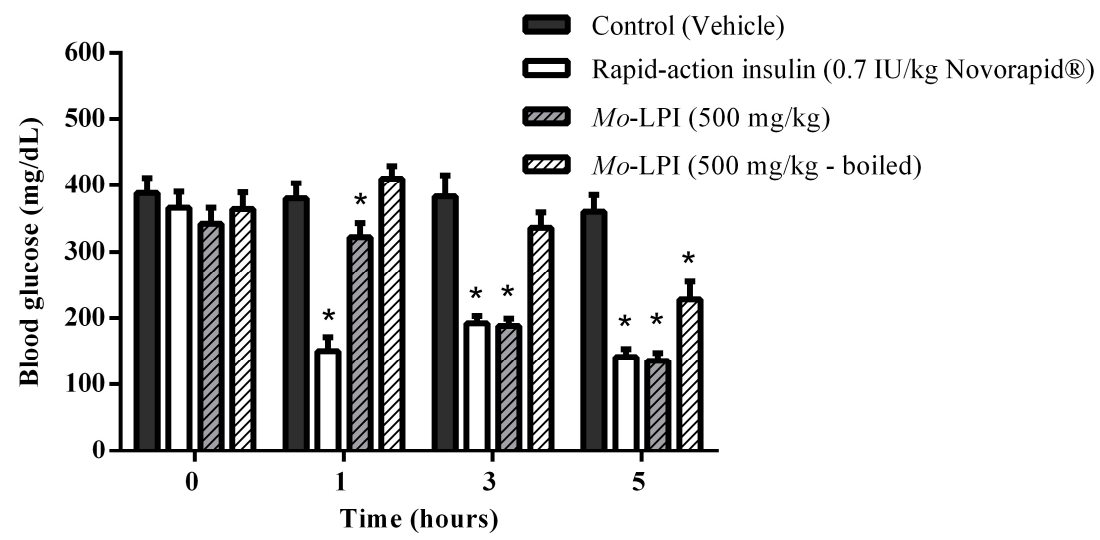

Figure 5. Influence of temperature on the hypoglycemic activity of Mo-LPI administered to alloxan-induced diabetic mice by intraperitoneal injection. Values are means \pm S.E.M. $(n=10)$. Control: vehicle (0.05 M Tris-HCl, pH 7.5, containing $0.15 \mathrm{M} \mathrm{NaCl})$. Mo-LPI unheated and previously boiled to $98^{\circ} \mathrm{C}$ for $1 \mathrm{~h}$. * Significant $(p<0.01)$ difference when compared with the corresponding value of the control at the same time. 


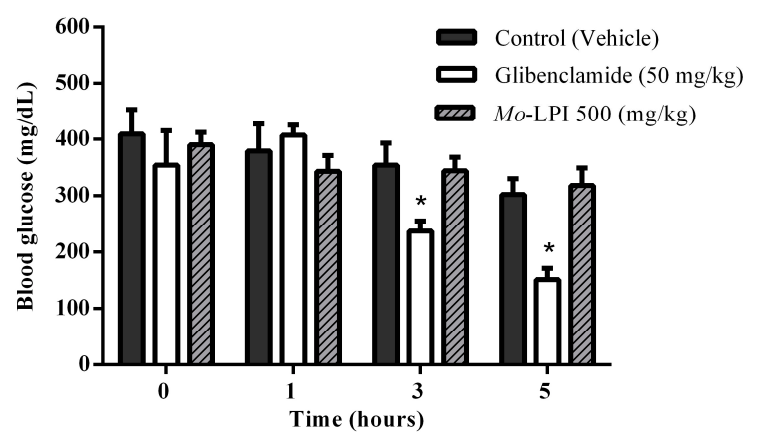

Figure 6. Effect of oral administration of Mo-LPI on blood glucose level in alloxan-induced diabetic mice. Values are means \pm S.E.M. $(n=10)$. Control: vehicle $(0.05 \mathrm{M}$ Tris- $\mathrm{HCl}, \mathrm{pH} 7.5,0.15 \mathrm{M} \mathrm{NaCl}) .{ }^{*}$ Significant $(p<0.01)$ difference when compared with the corresponding value of the control at the same time.

The effect of repeated i.p. administration of Mo-LPI on blood glucose levels is presented in Figure 7. When Mo-LPI ( $500 \mathrm{mg} / \mathrm{kg} \cdot \mathrm{bw})$ was administered along 7 days to alloxan-induced diabetic mice, a significant $(p<0.01)$ reduction $(56.2 \%)$ in blood glucose level was observed. Mo-LPI exhibited a glucose lowering effect in diabetic mice that was similar to that of insulin.

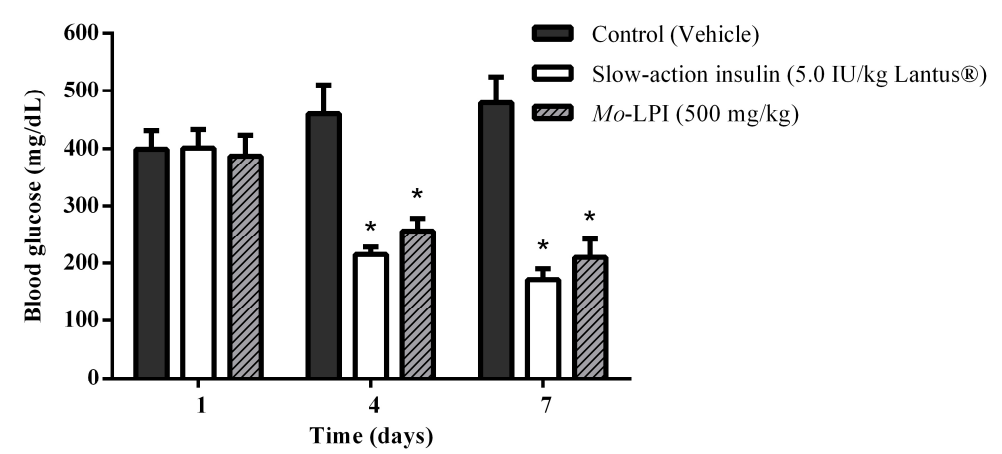

Figure 7. Effect of Mo-LPI on blood glucose level after seven consecutive days of intraperitoneal administration to alloxan-induced diabetic mice. Values are means \pm S.E.M. $(n=10)$. Control: vehicle $(0.05 \mathrm{M}$ Tris- $\mathrm{HCl}, \mathrm{pH} 7.5,0.15 \mathrm{M} \mathrm{NaCl}) .{ }^{*}$ Significant $(p<0.01)$ difference when compared with the corresponding value of the diabetic control.

\subsection{Effect of Mo-LPI on Serum Insulin Level}

Mo-LPI at a dose of $500 \mathrm{mg} / \mathrm{kg}$ did not affect the serum insulin level (Figure 8), suggesting that this protein isolate does not stimulate the insulin secretion in diabetic mice.

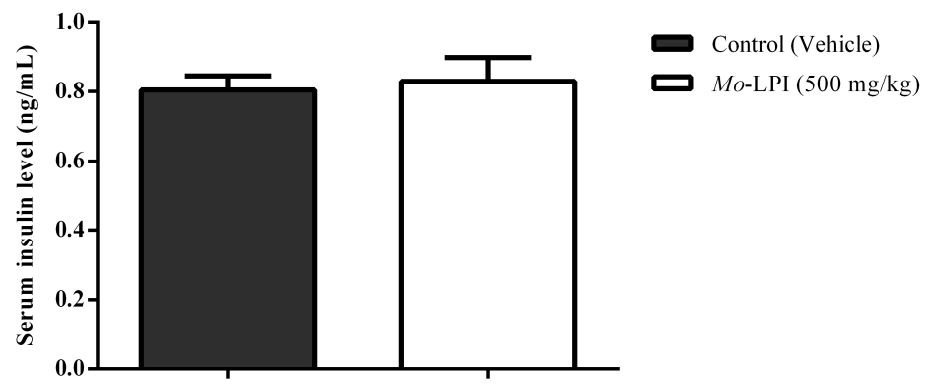

Figure 8. Effect of Mo-LPI on serum insulin level in alloxan-induced diabetic mice. Values are means \pm S.E.M. $(n=10)$. Five hours after Mo-LPI or $0.15 \mathrm{M} \mathrm{NaCl}$ i.p. administration in alloxan-diabetic mice, blood samples were collected via cardiac puncture to assay the insulin level. Control: vehicle (0.05 M Tris- $\mathrm{HCl}$, pH 7.5, containing $0.15 \mathrm{M} \mathrm{NaCl}$ ). 


\subsection{Effect of Mo-LPI on Lipid Peroxidation and Antioxidant Enzymes in Alloxan-Induced Diabetic Mice}

Table 1 shows the effect of Mo-LPI on liver lipid peroxidation and antioxidant enzymes in diabetic mice. Significant $(p<0.05)$ increases $(71.4 \%$ and $82.5 \%$, respectively) in malondialdehyde (MDA) levels were seen in both control and insulin-treated diabetic groups compared to the non-diabetic group. MDA level in diabetic mice treated with Mo-LPI was found to be similar to the non-diabetic group. Catalase (CAT) activity increased as a result of Mo-LPI administration (56.8\%) in comparison to diabetic control. No significant $(p<0.05)$ change of CAT activity was observed in both non-diabetic, diabetic control and insulin-treated diabetic groups. Superoxide dismutase (SOD) activities were similar in diabetic control and Mo-LPI-treated diabetic mice. These activities were significantly $(p<0.05)$ lower (73.2\% and $68.3 \%$, respectively) when compared with the values recorded in the non-diabetic and insulin-treated diabetic groups.

Table 1. Malondialdehyde levels and antioxidant enzyme activities in hepatic tissues of non-diabetic and alloxan-induced diabetic mice.

\begin{tabular}{|c|c|c|c|}
\hline Group & MDA ( $\mu \mathrm{mol} / \mathrm{g}$ Tissue) & 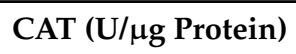 & 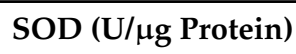 \\
\hline Diabetic control & $57.43 \pm 3.48^{a}$ & $1.92 \pm 0.18^{a}$ & $0.42 \pm 0.02^{a}$ \\
\hline Non-diabetic & $33.50 \pm 4.23^{b}$ & $1.88 \pm 0.23^{a}$ & $1.42 \pm 0.06^{b}$ \\
\hline D + Insulin (0.7 IU / kg) & $61.13 \pm 3.58^{a}$ & $2.01 \pm 0.16^{\mathrm{a}}$ & $1.20 \pm 0.04^{\mathrm{c}}$ \\
\hline $\mathrm{D}+\mathrm{Mo}-\mathrm{LPI}(500 \mathrm{mg} / \mathrm{kg})$ & $27.78 \pm 2.15^{b}$ & $3.01 \pm 0.35^{b}$ & $0.38 \pm 0.02^{a}$ \\
\hline
\end{tabular}

Values are means \pm S.E.M. $(n=10)$. Diabetic control: vehicle $(0.05 \mathrm{M}$ Tris- $\mathrm{HCl}, \mathrm{pH} 7.5$, containing $0.15 \mathrm{M} \mathrm{NaCl})$; Non-diabetic: vehicle ( $0.05 \mathrm{M}$ Tris-HCl, pH 7.5, containing $0.15 \mathrm{M} \mathrm{NaCl}) ; \mathrm{D}+$ insulin: diabetic mice + rapid-acting human recombinant insulin $\left(0.7 \mathrm{IU} / \mathrm{kg} \cdot \mathrm{bw}\right.$, Novorapid $\left.^{\circledR}\right)$; D + Mo-LPI: diabetic mice + Mo-LPI (500 mg $\left./ \mathrm{kg} \cdot \mathrm{bw}\right)$. Different letters in the same column indicate significant differences $(p<0.05)$ when compared with the corresponding value of the diabetic control.

\subsection{Behavioral Effect and Toxicity of Mo-LPI}

In the acute toxicity study, no death was reported for $72 \mathrm{~h}$ after i.p. administration of $M o$-LPI at a dose of $2500 \mathrm{mg} / \mathrm{kg} \cdot \mathrm{bw}$. In fact, mice treated with Mo-LPI did not show any change in their behavioral pattern. There was also no significant difference in body weight or food consumption when compared with the vehicle-treated group $(0.05 \mathrm{M}$ Tris- $\mathrm{HCl}, \mathrm{pH} 7.5$, containing $0.15 \mathrm{M} \mathrm{NaCl})$. Thus, it was concluded that Mo-LPI is safe at $2500 \mathrm{mg} / \mathrm{kg} \cdot \mathrm{bw}$, which is five times higher than the dose which was most effective for reducing the blood glucose level.

\section{Discussion}

There are several studies suggesting that plant proteins act as hypoglycemic agents $[23,24]$. This evidence encouraged us to assess the hypoglycemic effect of Mo-LPI, which is considered a pure source of protein, in diabetic mice. The procedure employed to obtain Mo-LPI is simple and useful, and basically consists of aqueous extraction, ammonium sulfate precipitation and dialysis, resulting in a good yield of protein: From $1 \mathrm{~g}$ of leaf dry weight, approximately $5 \mathrm{mg}$ of $\mathrm{Mo}$-LPI can be routinely obtained. The proteinaceous nature of Mo-LPI was confirmed by its elevated susceptibility to digestion by pepsin and trypsin. Actually, it has been reported that processing steps such as washing and dialysis minimize the effects of some factors, such trypsin inhibitors, phytates and polyphenols, leading to enhanced digestibility of the plant protein concentrates/isolates [25]. Indeed, Mo-LPI is a rich protein source as observed by SDS-PAGE. A lectin is likely to be one of the proteins since Mo-LPI agglutinated mouse and rat erythrocytes. This activity of Mo-LPI is selective since no agglutination was observed with rabbit erythrocytes. Furthermore, the agglutination activity of Mo-LPI could not be further increased by trypsin treatment of erythrocytes. Several plant lectins show similar behavior [26,27]. The importance of detecting lectins in Mo-LPI relies on the fact that there are some reports of hypoglycemic activity in vivo of plant hemagglutinins [9-11,21]. 
Another property demonstrated by Mo-LPI was its ability to cross-react with an anti-insulin antibody, suggesting the existence of common antigenic epitopes between Mo-LPI and insulin. Similar immunoreactivity was observed with proteins isolated from Canavalia ensiformis seed coat [7] and Bauhinia variegata leaf [28] when in the presence of human anti-insulin antibody. Additionally, Mo-LPI showed the same precipitation pattern exhibited by human recombinant insulin after addition of zinc. The zinc-insulin complex is highly insoluble, forming aggregates that precipitate in aqueous solution [29].

To test whether Mo-LPI exerts hypoglycemic activity, an alloxan-induced diabetic mouse model was used. Alloxan causes a massive reduction in insulin release because it destroys the $\beta$-cells of the islets of Langerhans, inducing hyperglycemia [30]. Thus, the administration of alloxan (150 mg/ $\mathrm{kg} \cdot \mathrm{bw})$ to the fasted mice markedly increased blood glucose levels. Pharmacological tests confirmed that the i.p. injection of a single dose of Mo-LPI into mice reduced significantly $(p<0.01)$ the blood glucose level in a dose-dependent manner. From this study, it could be concluded that Mo-LPI at $500 \mathrm{mg} / \mathrm{kg} \cdot \mathrm{bw}$ caused the maximum reduction in blood glucose, corresponding to $34.3 \%, 60.9 \%$ and $66.4 \%$ after 1,3 and $5 \mathrm{~h}$, respectively; therefore, this dose was selected for further analyses. Mo-LPI induced slow and gradual glycemic reductions, whereas insulin caused a rapid reduction (65.9\%) in blood glucose within only $1 \mathrm{~h}$ of administration. In fact, hypoglycemic events are a fairly common side effect in individuals who use insulin therapy to control diabetes [31,32]. The effect of Mo-LPI $(500 \mathrm{mg} / \mathrm{kg} \cdot \mathrm{bw}$ ) was also evidenced in the repeated dose test: A 56.2\% reduction in the blood glucose level was observed on the 7th day after i.p. administration. Subcutaneous (s.c.) and i.p. administration of a protein (M.Cy) isolated from Momordica cymbalaria in rats showed similar percent reductions $(66.0 \%$ and $69.0 \%$, respectively) in blood glucose [6]. Significant hypoglycemic effects were also observed in rats after i.p. and s.c. administration of a lectin isolated from Urtica pilulifera seeds and a protein extract from M. charantia fruits, which caused $28.0 \%$ and $43.0 \%$ reductions in blood glucose, respectively [9,33]. To further characterize Mo-LPI, the influence of temperature on its hypoglycemic effect was evaluated. After heat treatment of Mo-LPI (500 mg/kg.bw) at $98{ }^{\circ} \mathrm{C}$ for $1 \mathrm{~h}$, its hypoglycemic effect was only partially abolished: A $36.7 \%$ reduction in blood glucose was observed $5 \mathrm{~h}$ after i.p. administration. This result reveals that Mo-LPI exhibits resistance to high temperature, suggesting an increased structural stability that may contribute to the retention of its hypoglycemic effect. According to Gifoni et al. [34] and Katre et al. [35], proteins present in M. oleifera are often stable at high temperatures and this property could be related to the presence of cysteine residues in their structures.

In contrast, oral administration of Mo-LPI $(500 \mathrm{mg} / \mathrm{kg} \cdot \mathrm{bw})$ did not induce any hypoglycemic effects. It is reasonable to assume that the absence of this effect is caused by proteolysis of Mo-LPI along the digestive tract based on its susceptibility to pepsin and trypsin digestion (demonstrated under in vitro conditions). Similarly, the M.Cy protein of M. cymbalaria produced a hypoglycemic effect after i.p. administration but not when given orally [6]. In addition, treatment with glibenclamide, an insulin secretagogue, at a dose of $50 \mathrm{mg} / \mathrm{kg} \cdot \mathrm{bw}$ resulted in $33 \%$ and $50 \%$ reductions in blood glucose after $3 \mathrm{~h}$ and $5 \mathrm{~h}$, respectively, suggesting the presence of functional pancreatic $\beta$ cells.

Some plant compounds promote hypoglycemic effect by stimulating the secretion of insulin by the pancreatic $\beta$ cells $[36,37]$. This is the mechanism of action of sulfonylureas, a class of antidiabetic drugs widely used in the treatment of type 2 diabetes [38]. In order to evaluate the possible mechanism of action of Mo-LPI, its effect on insulin secretion was investigated. Mo-LPI showed the hypoglycemic effect without increasing serum insulin in alloxan-induced diabetic mice. Consequently, the mechanism of action of Mo-LPI in diabetic mice does not involve stimulation of insulin secretion. Further trials will be conducted in future studies to gather more data about the mechanism of action of Mo-LPI.

Increased generation of reactive oxygen species (ROS) is an important aspect in the pathophysiology of diabetes. ROS can damage cellular components, such as proteins, DNA and lipids, resulting in the development of diabetic complications and worsening glycemic control [39]. Products of lipid peroxidation, such as MDA, is elevated with ROS increase being frequently used as markers of oxidative stress. SOD e CAT are important antioxidant enzymes that prevent this 
process by ROS elimination [40]. Our present study was also undertaken to assess the oxidative status of liver after treatment with Mo-LPI by measuring the level of MDA and the activities of SOD and CAT. MDA level in alloxan-induced diabetic mice was found to be higher than that in non-diabetic mice. This could be due to the establishment of chronic hyperglycemia and effect of alloxan [41]. Treatment of diabetic mice with Mo-LPI (500 mg/ kg.bw; i.p.) in a repeated dose protocol had the ability to prevent lipid peroxidation since the MDA level was close to that observed in the non-diabetic group. In contrast, insulin treatment was not able to reduce MDA levels. It is possible that a transient postprandial hyperglycemia has been more prolonged in the insulin-treated mice than in those treated with Mo-LPI. Persistent hyperglycemia can induce ROS generation even after normalizing the blood sugar levels, a phenomenon known as hyperglycemic memory [42]. Regarding antioxidant enzymes, no change of SOD activity between Mo-LPI-treated and diabetic control mice was detected. SOD activity in insulin-treated diabetic mice was higher than in those groups. In fact, insulin stimulates SOD activity [43]. As for the CAT, there was no difference between the insulin-treated diabetic and diabetic control groups, whereas Mo-LPI-treated animals showed the highest activity. This result may explain the reduction in MDA level promoted by Mo-LPI. Hypoglycemic extracts of Terminalia paniculata, Tectona grandis and Potentilla discolor have been shown to restore the antioxidant enzyme activities and normalize or minimize lipid peroxidation in chemical-induced diabetic animals [44-46].

To offer more effective and less toxic treatment, any candidate substance to be used as a therapeutic agent must be tested on its toxicity. Thus, a mice acute toxicity assay with Mo-LPI was performed. This protein isolate showed no toxicity at a dose of $2500 \mathrm{mg} / \mathrm{kg} \cdot \mathrm{bw}$, as no death was reported by $72 \mathrm{~h}$. Additionally, no gross pathological changes were observed. Consequently, the $\mathrm{LD}_{50}$ of Mo-LPI in mice by i.p. administration is $>2500 \mathrm{mg} / \mathrm{kg}$.bw. In contrast, i.p. administration of an aqueous extract of $M$. oleifera leaves has been shown to cause $80 \%$ mortality at a dose of $2000 \mathrm{mg} / \mathrm{kg} \cdot \mathrm{bw}$ [47]. Because Mo-LPI is obtained from an aqueous extract of leaves, it is possible that the toxic components were lost during its preparation process.

\section{Materials and Methods}

\subsection{Plant Material}

Fresh M. oleifera leaves were harvested from trees naturally growing at Pici Campus from Federal University of Ceara (UFC, Fortaleza, Brazil), throughout the years of 2014 and 2015. Voucher specimens (EAC 54112) were deposited at the Herbário Prisco Bezerra, UFC. M. oleifera is an introduced species that is not native from Brazil and thus specific permissions from local authorities to obtain its leaves to be used in the present work were not required. Once harvested, leaves were used to obtain the protein isolate.

\subsection{Animals}

Conventional male mice, three weeks old, of Biocen-UFC outbred stock originally from Unib:SW (Swiss) (Unicamp, 1965, São Paulo, Brazil) mouse stock were provided by the Central Animal Facility of UFC (Fortaleza, Brazil). The animals were housed at the Department of Biology, at the same University, with temperature $\left(23.0 \pm 2.0^{\circ} \mathrm{C}\right)$, photoperiod $(12 \mathrm{~h}$ of light $/ 12 \mathrm{~h}$ of dark) and humidity $(45 \%-55 \%)$ monitored. The mice were kept in adequate numbers in polypropylene cages with pine shavings as substrate and water and feed (Biobase, Bio-Tec, São Paulo, Brazil) ad libitum until they reach the approximate weight of $30-50 \mathrm{~g}$.

All experimental procedures were performed in accordance with the current guidelines for the care of laboratory animals (including the use of the 3Rs procedures) and were reviewed and approved by the Animal Ethics Committee (CEPA) of UFC, Brazil (protocol number: 55/2012). This Committee was aware that the possibility of death and suffering of the animals was minimum considering the familiarization with the used protocol and the mice strain. 


\subsection{Obtention of Mo-LPI}

M. oleifera leaves were washed with distilled water, surface-dried with filter paper and pulverized in liquid nitrogen. The fine powder was extracted in $0.05 \mathrm{M}$ Tris- $\mathrm{HCl}$ buffer, $\mathrm{pH} 8.0$, containing $0.15 \mathrm{M}$ $\mathrm{NaCl}, 2 \%(w / v)$ polyvinylpolypyrrolidone (PVPP), $0.001 \mathrm{M}$ phenylmethysulfonyl fluoride (PMSF) and $0.01 \mathrm{M}$ ethylenediaminetetraacetic acid (EDTA), (1:5, w/v), under agitation at $4{ }^{\circ} \mathrm{C}$ for $30 \mathrm{~min}$. The suspension was filtered through a layer of cheesecloth and the filtrate centrifuged at $15,000 \times g$ for 30 min at $4{ }^{\circ} \mathrm{C}$. The crude extrac $t$ was precipitated at $90 \%$ saturation with ammonium sulfate and allowed to stand overnight. The precipitated proteins were separated by centrifugation as before, dissolved in and dialyzed against distilled water (MW cut-off of $2 \mathrm{kDa}$ ) and subsequently lyophilized. This protein isolate (Mo-LPI) was used for further analyses.

\subsection{Protein Determination}

Soluble proteins were quantified by the method described by Bradford [22] using bovine serum albumin (BSA) as standard.

\subsection{In Vitro Digestibility}

The in vitro digestibility of Mo-LPI was assessed using two proteases commonly found in the gastrointestinal tract of mammals [48], pepsin (EC 3.4.23.1; 2500-3500 U/mg protein, from porcine gastric mucosa) and trypsin (EC 3.4.21.4; 10,000 BAEE U/mg protein, from bovine pancreas). Mo-LPI ( $2 \mathrm{mg}$ ) was suspended in $200 \mu \mathrm{L}$ of $0.1 \mathrm{M} \mathrm{HCl}, \mathrm{pH} 1.8$ for pepsin or $0.1 \mathrm{M}$ Tris- $\mathrm{HCl}, \mathrm{pH} 8.1$ for trypsin digestion and incubated for $10 \mathrm{~min}$ at $37^{\circ} \mathrm{C}$ followed by addition of enzyme $(1 \mathrm{mg} / \mathrm{mL})$ at a 1:10 enzyme:substrate ratio. The mixtures containing Mo-LPI and pepsin or trypsin were incubated in a shaker water bath at $37^{\circ} \mathrm{C}$ for $4 \mathrm{~h}$. Aliquots $(25 \mu \mathrm{L})$ of both enzyme digestions were removed at 0 , 2 and $4 \mathrm{~h}$ intervals and $25 \mu \mathrm{L}$ of a $4 \times$ concentrated electrophoresis sample buffer $(0.125 \mathrm{M}$ Tris- $\mathrm{HCl}$ buffer, $\mathrm{pH} 6.8$, containing $0.1 \%(w / v)$ SDS) was added. The digests were immediately heated in boiling water $\left(98{ }^{\circ} \mathrm{C}\right)$ for $5 \mathrm{~min}$ and analyzed by SDS-PAGE using a vertical system containing a $12.5 \%(w / v)$ polyacrylamide gel [49]. Electrophoresis was carried out at a constant current of $20 \mathrm{~mA}$. BSA was used as a control to evaluate the enzymatic activity of pepsin and trypsin used. Protein bands were visualized with silver nitrate [50].

\subsection{Hemagglutinating Activity}

Two-fold serial dilutions of $\mathrm{Mo}$-LPI $(6 \mathrm{mg} / \mathrm{mL})$ in $0.15 \mathrm{M} \mathrm{NaCl}$ were incubated with $100 \mu \mathrm{L}$ of a $2 \%$ erythrocyte suspension and cell agglutination was scored after $30 \mathrm{~min}$ at $37^{\circ} \mathrm{C}$ and an additional $30 \mathrm{~min}$ at room temperature $\left(22 \pm 3^{\circ} \mathrm{C}\right)$ [51]. Hemagglutinating activity was assayed using rabbit, mouse and rat erythrocytes treated or not treated with trypsin [52]. The minimal protein concentration after serial dilution still promoting visible agglutination with naked eyes was taken to calculate the hemagglutinating activity.

\subsection{Dot Blot}

The presence of proteins in Mo-LPI that were able to cross-react with human anti-insulin antibodies was investigated by dot blot analysis [53]. Mo-LPI aliquots $(20 \mu \mathrm{L})$ were applied to a polyvinylidene difluoride (PVDF) membrane. After washing with Tris-buffered saline (0.5 M Tris base, $0.15 \mathrm{M} \mathrm{NaCl}$, $\mathrm{pH} 8.4$ ) containing $0.05 \%$ Tween 20 , nonspecific interactions were blocked by incubating the membrane in the same buffer plus $0.05 \%$ casein for $1 \mathrm{~h}$ at room temperature. The membrane was then washed again and incubated for an additional $3 \mathrm{~h}$ at room temperature with serial dilutions (1:250, 1:500 and 1:1000) of human anti-insulin IgG (Sigma-Aldrich, St Louis, MO, USA). Subsequently, a diluted solution (1:2000) of goat anti-rabbit IgG coupled to alkaline phosphatase (Sigma-Aldrich) was added. After $2 \mathrm{~h}$ at room temperature, the excess solution was removed by washing and the color reaction developed using 5-bromo-4-chloro-3-indolyl phosphate/nitro blue tetrazolium (BCIP/NBT) as substrate. Human 
recombinant insulin (Sigma-Aldrich) was used as a positive control and the primary antibody was diluted 1:250.

\subsection{Evaluation of Potential for Precipitation with Zinc}

Zinc-induced precipitation of Mo-LPI was evaluated based on previously published data using insulin [54]. Mo-LPI ( $5 \mathrm{mg} / \mathrm{mL}$ in $0.05 \mathrm{M}$ Tris- $\mathrm{HCl}$ buffer, $\mathrm{pH}$ 7.5) was mixed with $1 \mathrm{M}$ zinc chloride at a ratio of 5:2 $(v / v)$ and incubated for $12 \mathrm{~h}$ at room temperature. The same procedure was performed with zinc-free human recombinant insulin $(5 \mathrm{mg} / \mathrm{mL})$.

\subsection{Induction of Experimental Diabetes}

Hyperglycemia was induced in mice by a single i.p. injection of $150 \mathrm{mg} / \mathrm{kg} \cdot \mathrm{bw}$ alloxan monohydrate (Sigma-Aldrich) dissolved in $0.15 \mathrm{M} \mathrm{NaCl}$ after $16 \mathrm{~h}$ of fasting [55]. Blood samples were collected from the tail vein and the glucose level was determined using a clinical glucometer (AccuCheck Active ${ }^{\circledR}$, Roche, Indianapolis, IN, USA). The blood glucose level was checked before and $72 \mathrm{~h}$ after alloxan injection to confirm the development of diabetes. Animals with blood glucose levels $\geq 300 \mathrm{mg} / \mathrm{dL}$ were selected for the study.

\subsection{Single Dose Test in Alloxan Induced Diabetic Mice}

Three sets of experiments were carried out to test the acute hypoglycemic effect of Mo-LPI. In all studies, diabetic mice were previously fasted for $4 \mathrm{~h}$ and randomly divided into groups of ten animals each. Blood samples were obtained from the tail vein and glucose levels were measured just before treatment (time $0 \mathrm{~h}$ ) and 1,3 and $5 \mathrm{~h}$ later in all experiments.

In the first experiment, the acute effect of different doses of Mo-LPI administered by i.p. injection was examined. The animals were assigned into five groups. Group I (diabetic control or DC): diabetic mice + vehicle ( $0.05 \mathrm{M}$ Tris-HCl, $\mathrm{pH} 7.5$, containing $0.15 \mathrm{M} \mathrm{NaCl})$; Group II (D + insulin or positive control): diabetic mice + rapid-acting human recombinant insulin $\left(0.7 \mathrm{IU} / \mathrm{kg} \cdot \mathrm{bw}\right.$, Novorapid $\left.^{\circledR}\right)$ and Groups III, IV and V (D + Mo-LPI): diabetic mice + Mo-LPI at doses of 100, 300 and $500 \mathrm{mg} / \mathrm{kg} \cdot \mathrm{bw}$, respectively.

In the second test, the influence of temperature on the hypoglycemic activity of Mo-LPI was evaluated using the same administration route (i.p.). In this case, four groups were used. Groups I and II were treated as described previously; Group III (D + Mo-LPI): diabetic mice + Mo-LPI ( $500 \mathrm{mg} / \mathrm{kg} \cdot \mathrm{bw}$ ) and Group IV (D + Mo-LPI boiled): diabetic mice + Mo-LPI ( $500 \mathrm{mg} / \mathrm{kg} \cdot \mathrm{bw})$ previously boiled at $98^{\circ} \mathrm{C}$ for $1 \mathrm{~h}$.

Lastly, the third trial was conducted to examine whether Mo-LPI displays an oral hypoglycemic effect. Thus, three groups were used. Group I was treated as described previously; Group II (D + glibenclamide or positive control): diabetic mice + glibenclamide $(50 \mathrm{mg} / \mathrm{kg} \cdot \mathrm{bw})$ and Group III (D + Mo-LPI): diabetic mice + Mo-LPI $(500 \mathrm{mg} / \mathrm{kg} \cdot \mathrm{bw})$.

After the last blood glucose measurement in the three sets of experiments, the animals were euthanized by cervical dislocation.

\subsection{Repeated Dose Test in Alloxan Induced Diabetic Mice}

To evaluate the effects of repeated doses of Mo-LPI, diabetic animals were treated with the most effective dose identified by the single dose test $(500 \mathrm{mg} / \mathrm{kg} \cdot \mathrm{bw})$ and subjected to the procedure described by Djomeni et al. [56], with some modifications. Briefly, the freshly prepared solutions were intraperitoneally administered once daily for 7 consecutive days after $4 \mathrm{~h}$ of fasting. The diabetic mice were randomly assigned into three groups of ten animals each. Group I (diabetic control or DC): diabetic mice + vehicle (0.05 M Tris- $\mathrm{HCl}$, pH 7.5, containing $0.15 \mathrm{M} \mathrm{NaCl})$; Group II (D + insulin or positive control): diabetic mice + very slow-acting human recombinant insulin $\left(5.0 \mathrm{IU} / \mathrm{kg} \cdot \mathrm{bw}\right.$, Lantus $\left.{ }^{\circledR}\right)$ and Group III (D + Mo-LPI): diabetic mice + Mo-LPI $(500 \mathrm{mg} / \mathrm{kg} \cdot \mathrm{bw})$. Following $4 \mathrm{~h}$ of fasting, the blood glucose levels were assessed just before and at the end of 3- and 7-day treatment periods. 
At the end of the experiment, the animals were slightly sedated with halothane and euthanized by cervical dislocation.

\subsection{Serum Insulin Measurement}

Blood glucose was measured $5 \mathrm{~h}$ after the Mo-LPI administration in a single dose $(500 \mathrm{mg} / \mathrm{kg} \cdot \mathrm{bw}$, i.p.). The animals were sacrificed by cervical dislocation and blood samples immediately collected via cardiac puncture using a $21 \mathrm{G} 1$ needle attached to a $5 \mathrm{~mL}$ syringe. The samples were collected in tubes with no anticoagulant, allowed to stand at room temperature for $30 \mathrm{~min}$ and centrifuged at $3000 \times g$ for $15 \mathrm{~min}$ at $4{ }^{\circ} \mathrm{C}$. Serum insulin levels were measured by ELISA, using the rat/mouse insulin ELISA kit (Merk Millipore, Darmstadt, Germany).

\subsection{Antioxidant Effect Evaluation}

At the end of the repeated dose test (Section 4.11), the animals were carefully dissected and the liver used for the assessment of antioxidant activity of Mo-LPI. For this, liver samples were homogenized in ice-cold $0.05 \mathrm{M}$ potassium phosphate buffer, $\mathrm{pH} 7.8$, to get a $10 \%(w / v)$ homogenate.

Lipid peroxidation was determined by measuring malondialdehyde (MDA) concentration, following the method proposed by Agar et al. [57]. The liver homogenate obtained was incubated at $37^{\circ} \mathrm{C}$ for $1 \mathrm{~h}$ and $400 \mu \mathrm{L}$ of $35 \%(v / v)$ perchloric acid added. After centrifugation at $8300 \times g$ for $10 \mathrm{~min}$, the supernatant was collected and $200 \mu \mathrm{L}$ of $1.2 \%(v / v)$ thiobarbituric acid added. The resulting mixture was further incubated at $95{ }^{\circ} \mathrm{C}$ for $30 \mathrm{~min}$ and aliquots were removed to measure absorbance at $532 \mathrm{~nm}$ in a microplate reader (Expert Plus Analytical, (Biochrom, Cambridge, UK)). A standard curve was built with known concentrations of 1,1,3,3-tetramethoxypropane and results expressed as micromoles of MDA produced per gram of tissue ( $\mu \mathrm{mol} / \mathrm{g}$ tissue).

Catalase (CAT) activity was measured according to the method described by Aebi [58]. The reaction mixture consisted of $20 \mu \mathrm{L}$ of $5 \%(w / v)$ liver homogenate and $2 \mathrm{~mL}$ of $0.05 \mathrm{M}$ potassium phosphate buffer, $\mathrm{pH} 7.8$, containing $0.01 \mathrm{M} \mathrm{H}_{2} \mathrm{O}_{2}$. Immediately thereafter, the absorbance at $230 \mathrm{~nm}$ was recorded. Catalase activity was expressed as units $/ \mu \mathrm{g}$ protein, where one unit is defined as the amount of enzyme required to decompose $1 \mathrm{nmol} \mathrm{H}_{2} \mathrm{O}_{2}$ per min at $25^{\circ} \mathrm{C}$.

Superoxide dismutase activity (SOD) was determined as described by Beauchamp and Fridovich [59], with modifications. The liver homogenate obtained was centrifuged at $12,000 \times g$ for $20 \mathrm{~min}$ at $4{ }^{\circ} \mathrm{C}$ and the supernatant collected. In a darkroom, $10 \mu \mathrm{L}$ of this supernatant, $1 \mathrm{~mL}$ reaction medium $(0.05 \mathrm{M}$ potassium phosphate buffer, $\mathrm{pH} 7.8,0.1 \mathrm{nM}$ ethylenediamine tetraacetic acid and $0.013 \mathrm{mM}$ L-methionine), $150 \mu \mathrm{L}$ of $0.75 \mu \mathrm{M}$ NBT and $300 \mu \mathrm{L}$ of $2 \mu \mathrm{M}$ riboflavin were mixed. The mixture was exposed to fluorescent light $(15 \mathrm{~W}, 15 \mathrm{~min})$ followed by absorbance measurements at $560 \mathrm{~nm}$. The results were expressed as units $/ \mu \mathrm{g}$ protein, where one unit of SOD is defined as the amount that inhibits the NBT photoreduction by $50 \%$.

\subsection{Acute Toxicity Assessment}

Ten mice (male and female) were treated (i.p.) with Mo-LPI at a dose of $2500 \mathrm{mg} / \mathrm{kg} \cdot \mathrm{bw}$. The animals were continuously observed up to $4 \mathrm{~h}$ and subsequently at 24 and $72 \mathrm{~h}$ after administration and signs of toxicity and mortality were recorded [60].

\subsection{Statistical Analysis}

The results are expressed as means \pm S.E.M. The statistical analysis was performed by one-way analysis of variance (ANOVA) followed by Tukey's multiple comparison test. However, in the assay for measurement of serum insulin, the results were analyzed using Student's $t$-test (two unpaired samples). The results were considered to be significantly different at $p<0.01$ or $p<0.05$. 


\section{Conclusions}

The findings of this study allow us to conclude that Mo-LPI has hypoglycemic effect in alloxan-induced diabetic mice and that its mode of action does not involve a secretagogue stimulation of insulin. Mo-LPI was also effective in reducing the oxidative stress in mice associated with diabetes. Moreover, Mo-LPI did not cause acute toxicity to mice, even at high dose, suggesting its potential for safe biotechnological applications. Taken together, these data support the use of proteins from $M$. oleifera leaves as an alternative or complementary agent to treat diabetes.

Acknowledgments: This work was supported by National Council for Scientific and Technological Development $(\mathrm{CNPq}$, Brasilia, Brazil) and Coordination for the Improvement of Higher Education Personnel (CAPES, Brasilia, Brazil).

Author Contributions: I.M.V., P.C.P. and D.O.B.S. conceived and designed the experiments; P.C.P., J.T.A.O., A.F.U.C., B.G.T.A., D.F.F., M.L.P., M.P.V., F.A.S. and T.C.M. performed the experiments; I.M.V., P.C.P., D.O.B.S. and A.F.U.C. analyzed the data; I.M.V., J.T.A.O. and A.F.U.C. contributed reagents/materials/analysis tools; I.M.V. and J.T.A.O. wrote the paper.

Conflicts of Interest: The authors declare no conflict of interest. The funding sponsors had no role in the design of the study; in the collection, analyses, or interpretation of data; in the writing of the manuscript, and in the decision to publish the results.

\section{References}

1. American Diabetes Association. Diagnosis and classification of diabetes. Diabetes Care 2016, 39, S13-S22.

2. Teugwa, C.M.; Boudjeko, T.; Tchinda, B.T.; Mejiato, P.C.; Zofou, D. Anti-hyperglycaemic globulins from selected Cucurbitaceae seeds used as antidiabetic medicinal plants in Africa. BMC Complement. Altern. Med. 2013, 13, 63. [CrossRef] [PubMed]

3. Li, W.L.; Zheng, H.C.; Bukuru, J.; De Kimpe, N. Natural medicines used in the traditional Chinese medical system for therapy of diabetes mellitus. J. Ethnopharmacol. 2004, 92, 1-21. [CrossRef] [PubMed]

4. Xavier-Filho, J.; Oliveira, A.E.A.; Silva, L.B.; Azevedo, C.R.; Venâncio, T.M.; Machado, O.L.T.; Oliva, M.L.; Fernandes, K.V.S.; Xavier-Neto, J. Plant insulin or glucokinin: A conflicting issue. Braz. J. Plant Physiol. 2003, 15, 67-78. [CrossRef]

5. Mentreddy, S.R. Medicinal plant species with potential antidiabetic properties. J. Sci. Food Agric. 2007, 87, 743-750. [CrossRef]

6. Rajasekhar, M.D.; Badri, K.R.; Kumar, K.V.; Kassetti, R.B.; Fatima, S.S.; Kumar, M.T.S.; Appa Rao, C. Isolation and characterization of a novel antihyperglycemic protein from the fruits of Momordica cymbalaria. J. Ethnopharmacol. 2010, 128, 58-62. [CrossRef] [PubMed]

7. Oliveira, A.E.A.; Machado, O.L.T.; Gomes, V.M.; Xavier-Neto, J.; Pereira, A.C.; Vieira, J.G.H.; Fernandes, K.V.S.; Xavier-Filho, J. Jack bean seed coat contains a protein with complete sequence homology to bovine insulin. Protein Pept. Lett. 1999, 6, 15-21.

8. Sheng, Q.; Yao, H.; Xu, H.; Ling, X.; He, T. Isolation of plant insulin from Momordica charantia seeds by gel filtration and RP-HPLC. Zhong Yao Cai 2004, 27, 414-416. [PubMed]

9. Kavalali, G.; Tuncel, H.; Göksel, S.; Hatemi, H.H. Hypoglycemic activity of Urtica pilulifera in streptozotocin-diabetic rats. J. Ethnopharmacol. 2003, 84, 241-245. [CrossRef]

10. Li, Q.; Ye, X.L.; Zeng, H.; Chen, X.; Li, X.G. Study on the extraction technology and hypoglycemic activity of lectin from Trichosanthes kirilowi. Zhong Yao Cai 2012, 35, 475-479. [PubMed]

11. Rocha, A.A.; Araújo, T.F.S.; Fonseca, C.S.M.; Mota, D.L.; Medeiros, P.L.; Paiva, P.M.G.; Coelho, L.C.B.B.; Correia, M.T.S.; Lima, V.L.M. Lectin from Crataeva tapia bark improves tissue damages and plasma hyperglycemia in alloxan-induced diabetic mice. Evid.-Based Complement. Altern. Med. 2013, 2013, 869305. [CrossRef] [PubMed]

12. Kar, A.; Choudhary, B.K.; Bandyopadhyay, N.G. Comparative evaluation of hypoglycaemic activity of some Indian medicinal plants in alloxan diabetic rats. J. Ethnopharmacol. 2003, 84, 105-108. [CrossRef]

13. Jaiswal, D.; Kumar Rai, P.; Kumar, A.; Mehta, S.; Watal, G. Effect of Moringa oleifera Lam. leaves aqueous extract therapy on hyperglycemic rats. J. Ethnopharmacol. 2009, 123, 392-396. [CrossRef] [PubMed] 
14. Gupta, R.; Mathur, M.; Bajaj, V.K.; Katariya, P.; Yadav, S.; Kamal, R.; Gupta, R.S. Evaluation of antidiabetic and antioxidant activity of Moringa oleifera in experimental diabetes. J. Diabetes 2012, 4, 164-171. [CrossRef] [PubMed]

15. Mbikay, M. Therapeutic potential of Moringa oleifera leaves in chronic hyperglycemia and dyslipidemia: A review. Front. Pharmacol. 2012, 3, 24. [CrossRef] [PubMed]

16. Pereira, M.L.; Oliveira, H.D.; Oliveira, J.T.A.; Gifoni, J.M.; Rocha, R.O.; Sousa, D.O.B.; Vasconcelos, I.M. Purification of a chitin-binding protein from Moringa oleifera seeds with potential to relieve pain and inflammation. Protein Pept. Lett. 2011, 18, 1078-1085. [CrossRef] [PubMed]

17. Sinha, M.; Das, D.K.; Bhattacharjee, S.; Majumdar, S.; Dey, S. Leaf extract of Moringa oleifera prevents ionizing radiation-induced oxidative stress in mice. J. Med. Food 2011, 14, 1167-1172. [CrossRef] [PubMed]

18. Mehta, K.; Balaraman, R.; Amin, A.H.; Bafna, P.A.; Gulati, O.D. Effect of fruits of Moringa oleifera on the lipid profile of normal and hypercholesterolaemic rabbits. J. Ethnopharmacol. 2003, 86, 191-195. [CrossRef]

19. Tende, J.A.; Ezekiel, I.; Dikko, A.A.U.; Goji, A.D.T. Effect of ethanolic leaves extract of Moringa oleifera on blood glucose levels of streptozotocin-induced diabetes and normoglycemic Wistar rats. Br. J. Pharmacol. Toxicol. 2011, 3, 1-4.

20. Francis, J.A.; Jayaprakasam, B.; Olson, L.K.; Nair, M.G. Insulin secretagogues from Moringa oleifera with cyclooxygenase enzyme and lipid peroxidation inhibitory activities. Helv. Chim. Acta 2004, 87, 317-326. [CrossRef]

21. Paula, P.C.; Oliveira, J.T.A.; Sousa, D.O.B.; Alves, B.G.T.; Carvalho, A.F.U.; Franco, O.L.; Vasconcelos, I.M. Insulin-like plant proteins as potential innovative drugs to treat diabetes-The Moringa oleifera case study. New Biotechnol. 2016. [CrossRef] [PubMed]

22. Bradford, M.M. A rapid and sensitive method for the quantitation of microgram quantities of protein utilizing the principle of protein-dye binding. Anal. Biochem. 1976, 72, 248-254. [CrossRef]

23. Venancio, T.M.; Oliveira, A.E.A.; Silva, L.B.; Machado, O.L.T.; Fernandes, K.V.S.; Xavier-Filho, J. A protein with amino acid sequence homology to bovine insulin is present in the legume Vigna unguiculata (cowpea). Braz. J. Med. Biol. Res. 2003, 36, 1167-1173. [CrossRef] [PubMed]

24. Khanna, P.; Jain, S.C.; Panagariya, A.; Dixit, V.P. Hypoglycemic activity of polypeptide-p from a plant source. J. Nat. Prod. 1981, 44, 648-655. [CrossRef] [PubMed]

25. Aleator, $\mathrm{O}$. Protein quality evaluation and in vitro multi-enzyme digestibility of some plant protein isolates and concentrates. Arch. Zootech. 2012, 15, 5-16.

26. Oliveira, J.T.A.; Melo, V.M.M.; Câmara, M.F.L.; Vasconcelos, I.M.; Beltramini, L.M.; Machado, O.L.T.; Gomes, V.M.; Pereira, S.P.; Fernandes, C.F.; Nunes, E.P.; et al. Purification and physicochemical characterization of a cotyledonary lectin from Luetzelburgia auriculata. Phytochemistry 2002, 61, 301-310. [CrossRef]

27. Raman, B.V.; Sravani, B.; Rekha, P.P.; Lalitha, K.V.N.; Rao, B.N. Effect of plant lectins on human blood group antigens with special focus on plant foods and juices. Int. J. Res. Ayurveda Pharm. 2012, 3, 255-263.

28. Azevedo, C.R.; Maciel, F.M.; Silva, L.B.; Ferreira, A.T.S.; Da Cunha, M.; Machado, O.L.T.; Fernandes, K.V.S.; Oliveira, A.E.A.; Xavier-Filho, J. Isolation and intracellular localization of insulin-like proteins from leaves of Bauhinia variegata. Braz. J. Med. Biol. Res. 2006, 39, 1435-1444. [CrossRef] [PubMed]

29. Gualandi-Signorini, A.M.; Giorgi, G. Insulin formulations: A review. Eur. Rev. Med. Pharmacol. Sci. 2001, 5, 73-83. [PubMed]

30. Fischer, J. Drugs and chemicals that produce diabetes. Trends Pharmacol. Sci. 1985, 6, 72-75. [CrossRef]

31. Cryer, P.E.; Davis, S.N.; Shamoon, H. Hypoglycemia in diabetes. Diabetes Care 2003, 26, 1902-1912. [CrossRef] [PubMed]

32. McCrimmon, R.J.; Sherwin, R.S. Hypoglycemia in type 1 diabetes. Diabetes 2010, 59, 2333-2339. [CrossRef] [PubMed]

33. Yibchok-Anun, S.; Adisakwattana, S.; Yao, C.Y.; Sangvanich, P.; Roengsumran, S.; Hsu, W.H. Slow acting protein extract from fruit pulp of Momordica charantia with insulin secretagogue and insulinomimetic activities. Biol. Pharm. Bull. 2006, 29, 1126-1131. [CrossRef] [PubMed]

34. Gifoni, J.M.; Oliveira, J.T.A.; Oliveira, H.D.; Batista, A.B.; Pereira, M.L.; Gomes, A.S.; Oliveira, H.P.; Grangeiro, T.B.; Vasconcelos, I.M. A novel chitin-binding protein from Moringa oleifera seed with potential for plant disease control. Biopolymers 2012, 98, 406-415. [CrossRef] [PubMed] 
35. Katre, U.V.; Suresh, C.G.; Khan, M.I.; Gaikwad, S.M. Structure-activity relationship of a hemagglutinin from Moringa oleifera seeds. Int. J. Biol. Macromol. 2008, 42, 203-207. [CrossRef] [PubMed]

36. Cui, J.; Li, Y.-W.; Jia, N.; Song, X.-M.; Duan, J.-L.; Weng, Y.; Guan, Y.; Zhou, D.; Wang, L.; Xi, M.M.; et al. Insulin-secretagogue activity of eleven plant extracts and twelve pure compounds isolated from Aralia taibaiensis. Life Sci. 2013, 92, 131-136. [CrossRef] [PubMed]

37. Huang, D.; Jiang, Y.; Chen, W.; Yao, F.; Huang, G.; Sun, L. Evaluation of hypoglycemic effects of polyphenols and extracts from Penthorum chinense. J. Ethnopharmacol. 2015, 163, 256-263. [CrossRef] [PubMed]

38. Kudaravalli, J.; Vijayalakshmi, G.; Kishore, K.K. Safety and efficacy of sulfonylurea drugs in type 2 diabetes mellitus. Apollo Med. 2013, 10, 165-168. [CrossRef]

39. Nishikawa, T.; Edelstein, D.; Du, X.L.; Yamagishi, S.; Matsumura, T.; Kaneda, Y.; Yorek, M.A.; Beebe, D.; Oates, P.J.; Hammes, H.P.; et al. Normalizing mitochondrial superoxide production blocks three pathways of hyperglycaemic damage. Nature 2000, 404, 787-790. [PubMed]

40. Del Rio, D.; Stewart, A.J.; Pellegrini, N. A review of recent studies on malondialdehyde as toxic molecule and biological marker of oxidative stress. Nutr. Metab. Cardiovasc. Dis. 2005, 15, 316-328. [CrossRef] [PubMed]

41. Saio, V.; Syiem, D.; Sharma, R. Effect of Potentilla fulgens on lipid peroxidation and antioxidant status in alloxan-induced diabetic mice. J. Basic Clin. Pharm. 2012, 3, 249-254. [CrossRef] [PubMed]

42. Cencione, C.; Spallotta, F.; Greco, S.; Martelli, F.; Zeiher, A.M.; Gaetano, C. Epigenetic mechanisms of hyperglycemic memory. Int. J. Biochem. Cell Biol. 2014, 51, 155-158. [CrossRef] [PubMed]

43. Lima, V.B.S.; Sampaio, F.A.; Bezerra, D.L.C.; Neto, J.M.M.; Marreiro, D.N. Parameters of glycemic control and their relationship with zinc concentrations in blood and with superoxide dismutase enzyme activity in type 2 diabetes patients. Arq. Bras. Endocrinol. Metab. 2011, 55, 701-707.

44. Zhang, L.; Yang, J.; Chen, X.-Q.; Zan, K.; Wen, X.-D.; Chen, H.; Wang, Q.; Lai, M.-X. Antidiabetic and antioxidant effects of extracts from Potentilla discolor Bunge on diabetic rats induced by high fat diet and streptozotocin. J. Ethnopharmacol. 2010, 132, 518-524. [CrossRef] [PubMed]

45. Ramachandran, S.; Rajasekaran, A.; Manisenthil Kumar, K.T. Antidiabetic, antihyperlipidemic and antioxidant potential of methanol extract of Tectona grandis flowers in streptozotocin induced diabetic rats. Asian Pac. J. Trop. Med. 2011, 4, 624-631. [CrossRef]

46. Ramachandran, S.; Rajasekaran, A.; Manisenthil Kumar, K.T. Investigation of hypoglycemic, hypolipidemic and antioxidant activities of aqueous extract of Terminalia paniculata bark in diabetic rats. Asian Pac. J. Trop. Biomed. 2012, 2, 262-268. [CrossRef]

47. Awodele, O.; Oreagba, I.A.; Odoma, S.; Silva, J.A.T.; Osunkalu, V.O. Toxicological evaluation of the aqueous leaf extract of Moringa oleifera Lam. (Moringaceae). J. Ethnopharmacol. 2012, 139, 330-336. [CrossRef] [PubMed]

48. Sathe, S.K.; Sze-Tao, K.W.C.; Wolf, W.J.; Hamaker, B.R. Biochemical characterization and in vitro digestibility of the major globulin in cashew nut (Anacardium occidentale). J. Agric. Food Chem. 1997, 45, 2854-2860. [CrossRef]

49. Laemmli, U.K. Cleavage of structural proteins during the assembly of the bacteriophage T4. Nature 1970, 227, 679-685. [CrossRef]

50. Blum, H.; Beier, H.; Gross, H.J. Improved silver staining of plant proteins, RNA and DNA in polyacrylamide gels. Electrophoresis 1997, 8, 93-99. [CrossRef]

51. Moreira, R.A.; Perrone, J.C. Purification and partial characterization of a lectin from Phaseolus vulgaris. Plant Physiol. 1977, 59, 783-787. [CrossRef]

52. Lis, H.; Sharon, N. Soybean (Glycine max) agglutinin. Methods Enzymol. 1972, 28, 360-365.

53. Towbin, H.; Staehelin, T.; Gordon, J. Electrophoretic transfer of proteins from polyacrylamide gels to nitrocellulose sheets: Procedure and some applications. Proc. Natl. Acad. Sci. USA 1979, 76, 4350-4354. [CrossRef] [PubMed]

54. Hallas-Moller, K.; Petersen, K.; Schlichtkrull, J. Crystalline and amorphous insulin-zinc compounds with prolonged action. Science 1952, 116, 394-398. [CrossRef]

55. Kumar, D.; Kumar, S.; Kohli, S.; Arya, R.; Gupta, J. Antidiabetic activity of methanolic bark extract of Albizia odoratissima Benth. in alloxan induced diabetic albino mice. Asian Pac. J. Trop. Biomed. 2011, 1, 900-903. [CrossRef] 
56. Djomeni, P.D.D.; Tédong, L.; Asongalem, E.A.; Dimo, T.; Sokeng, S.D.; Kamtchouing, P. Hypoglycaemic and antidiabetic effect of root extracts of Ceiba pentandra in normal and diabetic rats. Afr. J. Tradit. Complement. Altern. Med. 2006, 3, 129-136. [CrossRef]

57. Agar, R.; Bosnak, M.; Amanvermez, R.; Demir, S.; Ayyildiz, M.; Celik, C. The effect of ethanol on lipid peroxidation and glutathione level in the brain stem of rat. Neuroreport 1999, 10, 1799-1801. [CrossRef] [PubMed]

58. Aebi, H. Catalase in vitro. Methods Enzimol. 1984, 105, 121-126.

59. Beauchamp, C.; Fridovich, I. Superoxide dismutase: Improved assays and an assay applicable to acrylamide gels. Anal. Biochem. 1971, 44, 276-287. [CrossRef]

60. Adedapo, A.A.; Mogbojuri, O.M.; Emikpe, B.O. Safety evaluations of the aqueous extract of the leaves of Moringa oleifera in rats. J. Med. Plants Res. 2009, 3, 586-591.

Sample Availability: Not applicable.

(C) 2017 by the authors; licensee MDPI, Basel, Switzerland. This article is an open access article distributed under the terms and conditions of the Creative Commons Attribution (CC BY) license (http:// creativecommons.org/licenses/by/4.0/). 